Language and Cognition 12 (2020), 526-563. doi:10.1017/langcog.2020.12

(C) UK Cognitive Linguistics Association 2020. This is an Open Access article, distributed under the terms of the Creative Commons Attribution licence (http://creativecommons.org/ licenses/by/4.0/), which permits unrestricted re-use, distribution, and reproduction in any medium, provided the original work is properly cited.

\title{
Lexically specific vs. productive constructions in L2 Finnish*
}

\author{
SIRKKU LESONEN \\ University of Groningen and University of Fyväskylä \\ RASMUS STEINKRAUSS \\ University of Groningen \\ MINNA SUNI \\ University of $\mathcal{F y v a ̈ s k y l a ̈ ~}$ \\ A N D \\ MARJOLIJN VERSPOOR \\ University of Groningen and University of Pannonia
}

(Received 4 October 2019 - Revised 24 March 2020 - Accepted 24 March 2020 -

First published online 18 fune 2020)

A B S T R A C T

It is assumed from a usage-based perspective that learner language constructions emerge from natural language use in social interaction through exemplar learning. In L1, young learners have been shown to develop their constructions from lexically specific, formulaic expressions into more productive, abstract schemas. A similar developmental path has been shown for L2 development, with some exceptions. The aim of the current study is to explore to what extent the default assumption holds for L2 learning. The development of two constructions was traced in four adults learning L2 Finnish. Free-response data, collected weekly over a period of 9 months, were used to investigate the productivity of the constructions. The results show that, contrary to the traditional assumption, L2 learners do not start off with only lexically specific expressions, but that both lexically specific and more productive constructions are used from the beginning. Our results therefore

[*] Address for correspondence: e-mail: sirkku.m.lesonen@jyu.fi 
suggest that, for educated adult L2 learners, the schema formation can happen rather quickly and even without the repetition of a specific lexical sequence.

KE Y W O R D S : usage-based learning, L2 learning, item-based development, construction, L2 Finnish.

\section{Introduction}

In usage-based approaches, language is seen as a structured inventory of symbolic units (Langacker, 1987), i.e., constructions. Constructions are form-meaning pairings that consist of a phonological pole (including orthographic representation) and a semantic pole. Each pole can evoke the other, and the symbolic nature of a construction resides in a link between the phonological and the semantic poles (Langacker, 2013). In usage-based linguistics, learning to use these symbolic structures is seen as an emergent process: through exemplar learning, a learner's individual inventory of constructions emerges from natural language use in social interaction (e.g., Ellis \& Cadierno, 2009; Tomasello, 2003).

The usage-based learning path is assumed to emerge from lexically specific towards schematized patterns (Peters, 1983; Tomasello, 2003). This has been established in a number of empirical studies of L1 (first language) development. For example, Dąbrowska and Lieven (2005) show that L1 learners' constructions develop in an item-based manner from lexically specific, formulaic expressions into more productive, abstract schemas.

This usage-based learning path has also been proposed as a "default" guideline (Ellis, 2002, p. 170) for investigating L2 (second language) development, and in some studies it has been shown that L2 learners also start with lexically specific expressions and gradually move towards more abstract constructions (e.g., Eskildsen, 2008; Mellow, 2006). However, especially Roehr-Brackin (2014) has shown that L2 learners may also use schematic constructions from the beginning.

The aim of this paper is to investigate whether the general assumption of item-based learning in L1 holds for L 2 learning in four individual cases. To do this, we traced the development over the course of nine months of two different but similar constructions (haluta 'want' and tykätä 'like') in four beginning L2 Finnish learners with different L1s.

\section{The usage-based learning trajectory}

According to Langacker (2013), language learning is a bottom-up process: the learner moves from lexically specific expressions towards more abstract and productive patterns. This development is enabled by general cognitive mechanisms such as association, categorization, schematization, and entrenchment.

As the learner is exposed to a target language, she or he learns to associate the phonological pole with the semantic pole (Langacker, 2013). For example, 
Haluan matkustaa will be associated with the meaning 'I want to travel'. In categorization, the learner compares novel utterances with utterances already encountered to form categories and discover similarities (Langacker, 2013). For example, when comparing Haluan matkustaa 'I want to travel' with Haluan syödä 'I want to eat', the learner may realize that these expressions denote wanting, and that both matkustaa and syödä denote desired actions and belong to the same group of words.

Schematization occurs when a learner encounters a number of target language expressions and extracts the commonalities inherent in them while at the same time ignoring differences between them (Langacker, 2013). During the process of schematization, the learner generalizes over lexically specific utterances and in this way develops abstract knowledge about the different parts of the construction and their communicative functions (Goldberg, 1995). For example, when the learner encounters the haluta 'want' construction with several different verbal complements (e.g., Haluan matkustaa 'I want to travel' and Haluan syödä 'I want to eat'), over time he or she will be able to develop the pattern haluan + non-finite clause (NFC) 'I want + NFC' based on the fact that these expressions all describe one's desire for different actions (semantic pole) and all show a similar form, haluan + verb stem $+\mathrm{A}^{1}$ (phonological pole). In other words, the learner develops a schema with an open slot for non-finite clauses. The generalities derive from the learner's experiences of using language for the purposes of interaction; in other words, they spring from usage events. (Eskildsen, 2008.)

Finally, entrenchment refers to the process of automatization: when a memory trace is repeatedly activated, it becomes established as a unit. An entrenched unit can be easily accessed and activated when necessary (Langacker, 2013).

To summarize, in usage-based approaches the learner is seen to move gradually from holistic, rote-learned, lexically specific formulas such as Haluan matkustaa Saksaan 'I want to travel to Germany', via semi-schematic, semi-abstract patterns such as Haluan matkustaa + noun phrase (NP) 'I want to travel + noun phrase $(\mathrm{NP})$, towards a more productive pattern, such as Haluan + NFC 'I want + NFC', possibly as far as a fully abstract schema 'verb + NFC'. (See, e.g., Dąbrowska \& Lieven, 2005; Eskildsen, 2008; Langacker, 2013; Tomasello, 2003.) All types of construction can become entrenched, co-existing in the speaker's individual linguistic inventory (Langacker, 2013).

Several L2 longitudinal studies confirm the commonly found L1 path of development, from lexically specific to more schematic patterns. Eskildsen (2008) shows that an L2 English learner's abstract can construction sprang from a specific multiword expression, I can write. He also showed that an L2 English learner initially used very few conjunctions in subordination

[1] Capital A stands for a vowel change, which can be either $a$ or $\ddot{a}$ depending on the vowels in the word, see VISK $\$ 15$. 
and coordination, supporting the idea of item-based learning (2018). Cross-sectional data show the same type of development. Roos and Lenzing (2018) suggest that, as proficiency increases, the use of formulaic sequences decreases and accounts for a smaller part of a speaker's production. These studies all suggest that L2 learners start from (at least to some extent) fixed expressions and over time move to more abstract ones, demonstrating more productive and flexible language use.

The question that arises is whether L2 learners only move from specific to abstract constructions in their development, or whether they may also already have more schematic and productive and flexible patterns in their linguistic inventory from early on. Langacker (2009) suggests that a productive, abstract schema can be developed even if "no specific lexical sequence is repeated" (2009, p. 633) and stored as a unit. For example, a learner may form an abstract pattern such as a verb and object with a directional by encountering various verbs of caused motion such as throw it away, pick it up, put it down, without learning any of these expressions individually. In other words, forming an abstract pattern does not necessarily start with the use of lexically specific chunks. In L2 learning, this kind of learning trajectory has been empirically established by Roehr-Brackin (2014) and Eskildsen (2015).

In Roehr-Brackin's study (2014), an L2 German learner's gehen 'go' construction was already initially abstract, in contrast to a similar, fahren 'drive', construction, which developed in an item-based fashion from lexically specific units into a more abstract pattern. Also, Eskildsen (2015) shows that an individual learner may use both lexically specific and more productive patterns in the initial phases of learning. For one adult L2 English learner, the initial use of declarative copula questions was more productive than that of interrogative copula questions.

There is also evidence from cross-sectional data that learners might actually start off with some general schemas. Arndt-Lappe and Baldus (2018) suggest that, because low-proficiency learners overgeneralized the investigated patterns (to-infinitival complements and penultimate stress in complex words in English), they formed a general schema and only later developed more finegrained sub-schemas. In other words, L2 learners may also use a top-down process, starting with very abstract generalizations and later moving to more specific schemas.

There are various reasons why both top-down and bottom-up processes may take place in L2 development, such as instruction and knowledge about other language systems, especially the L1. As far as L2 instruction is concerned, Roehr-Brackin (2014) argues that the L2 German learner's explicit knowledge may have sped up the schema formation for the initially abstract gehen construction. As far as the L1 is concerned, Gustafsson (2019) shows in her study of the development of conventionalized ways of saying things (CWOSTs) that L2 learners may not treat a beyond-word-level concept holistically and may 
not map it directly onto a conventionalized expression in L2. For example, the Dutch equivalent of the English expression to put money in the bank is geld op de bank zetten (literally: money on the bank put), and beginners frequently used the L2 English pattern put NP on DET (the definite article) bank, corresponding with L1 Dutch zet NP op de bank. Thus, when expressing the meaning D E P O S I T I N G MONEY, learners seem to first break down the concept into meaning units (process, thing, location), then search for linguistic solutions for them, and finally merge these fragments using the abstract verb-argument schema.

To summarize, previous research has established that, as with L1 acquisition, some L2 constructions develop in an item-based fashion. However, a few studies have shown that some L2 constructions are - at least to some extent schematic almost from the start. In usage-based linguistics, it is predicted that learners move towards more abstract constructions over time and even develop fully abstract representations. There is some empirical evidence for L2 learners' fully abstract knowledge (Eskildsen \& Cadierno, 2007), but the development of fully abstract constructions in L2 learning has also been questioned (see, e.g., Eskildsen, 2008). Constructing an L2 is assumed to be an ongoing process without an actual endpoint (Eskildsen, 2008), as is linguistic development in general (see Hopper, 1998). Therefore, it might be misguided to trace fully abstract L2 representations. A better question might be to ask about the extent to which L 2 constructions become more schematic and abstract over time. It has been shown that some constructions might lend themselves to abstraction more easily than others (Eskildsen, 2008), and there is also a lot of inter-individual variability in L2 learning.

The current study aims to explore these possible developmental patterns in more depth with longitudinal L2 developmental data in L2 Finnish. We traced four learners over a period of 9 months in their use of haluta 'want' and tykätä 'like'. The verbs were relatively frequent in our data and can be considered good material for comparison because they are similar both semantically and structurally: they can both be seen to express an evaluation towards something (see Lesonen, Suni, Steinkrauss, \& Verspoor, 2017), and they allow the same kinds of complements (see $\$ 3.3$ below). The term 'lexically specific' is used to refer to a construction in which the main verb, here haluta or tykätä, repeatedly takes the same form (e.g., the first person singular) and the lexical material in the complement shows little variation. The lexical specificity of constructions is investigated as evidenced in production, and is likely stemming from instances encountered in input. Productivity in this study is defined as variability within the construction: the more different forms of the main verb (i.e., haluta and tykätä) and the more different complements are used, the more productive the pattern is. As we will argue later, the level of productivity forms a continuum. 


\section{The study}

This study aims to explore the following questions:

1. Does the development of the haluta 'want' and tykätä 'like' constructions of four Finnish L2 learners start with lexically specific expressions?

2. Do these initial constructions develop into more abstract patterns over time?

Based on earlier studies we hypothesize that:

H1. Learners start mostly with lexically specific constructions, but constructions might also already be more abstract initially.

H2. Initial constructions develop into more abstract patterns, but learners will show different levels of abstractness in their constructions at the end of the period of observation.

\subsection{P A R T I C I P A N T S}

In this study, we traced the development of two verbal constructions in four adult Finnish L2 learners. These learners formed the entire group of students who took the same three consecutive language courses at the same Finnish university; originally c. 20 students were followed. The courses were each worth 5 ECTS (The European Credit Transfer and Accumulation System) and they consisted of 70 contact hours plus additional independent work. The first course was at level A1 in the European Framework of Reference for Languages (Common European Framework of Reference for Languages, Council of Europe, 2006). The second course was at level A2, and the third at level B1. All three courses were given during one academic year. The courses were taught by an L1 Finnish speaker, the first two courses by the first author, the third one by a colleague. The research questions were set after the data collection and therefore the study did not have an impact on teaching.

Background information on the participants is presented in Table 1.

\subsection{DATA COLLECTION}

The data were collected weekly and include both written and spoken data. The data are free-response data. The topics were chosen in accordance with the participants' language proficiency, and similar topics were covered in the classroom, although the tasks themselves were not practiced in the classroom. The number of points of data collection is shown in Table 2.

The written data were produced by hand either during the contact lessons (with a time limit of approximately 20 minutes) or in the participants' free time (under supervision but without a time limit). The writing samples are on average 91 words long, the length ranging from 31 to 152 words. 
T A B LE 1. Background information on the participants

\begin{tabular}{|c|c|c|c|c|c|}
\hline Participant & Age & L1 & Other languages & $\begin{array}{l}\text { Time of } \\
\text { residence } \\
\text { before the } \\
\text { study }\end{array}$ & $\begin{array}{l}\text { Explicit } \\
\text { instruction } \\
\text { before the } \\
\text { study }\end{array}$ \\
\hline Lena & 23 & German & $\begin{array}{l}\text { English }^{1,2}, \text { French }^{1}, \\
\text { Icelandic }^{1,2}\end{array}$ & 0 & 0 \\
\hline Jungo & 22 & $\begin{array}{l}\text { Chinese } \\
\text { (Hunanese) }\end{array}$ & $\begin{array}{l}\text { Mandarin Chinese }{ }^{1} \text {, } \\
\text { English }^{1}\end{array}$ & 2 years & $\begin{array}{l}1 \text { Finnish } \\
\text { course of } \\
5 \text { ETCS, } \\
20 \text { hours } \\
\text { self } \\
\text { studying }\end{array}$ \\
\hline Alvaro & 30 & Spanish & $\begin{array}{l}\text { English }^{1}, \text { French }^{1,2}, \\
\text { Russian }^{1}\end{array}$ & 0 & 0 \\
\hline Khadiza & 31 & Bangla & $\begin{array}{l}\text { English }^{1}, \text { Hindi, } \\
\text { Urdu }\end{array}$ & 4 years & 0 \\
\hline
\end{tabular}

No TEs : ${ }^{1}$ learned in instructional setting; ${ }^{2}$ learned in target-language-speaking community.

T A B LE 2. Number of points of data collection

\begin{tabular}{llll}
\hline & Number of points of data collection & Written data & Spoken data \\
\hline Lena & 35 & 17 & 18 \\
Jungo & 35 & 18 & 17 \\
Alvaro & 33 & 16 & 17 \\
Khadiza & 28 & 16 & 12 \\
\hline
\end{tabular}

The spoken data were recorded in a language studio, with a recorder (Roland R-05); with Lena, a smart phone was used once. The spoken data comprise both monologues and dialogues. The participants' speaking partner in the dialogues was either another L2 speaker or sometimes an L1 Finnish speaker. Mostly, the L1 speaker in the dialogues was the first author of this paper. Since the research questions were set after the data collection, this double role should not have an impact on the data collection. The speaking samples are on average 218 words long (range 44-518 words).

\subsection{TARGETED L 2 CONSTRUCTIONS}

In this study, the language units under investigation are learner language constructions. Constructions are form-meaning mappings consisting of two poles (Goldberg, 2006). According to Goldberg, one characteristic of a construction is that a certain aspect in its meaning or form is not strictly predictable from the components of the construction. For example, the meaning of the 
tykätä 'like' construction ${ }^{2}$ (see example (1)) cannot be predicted from its parts: the stem of the verb tykät $\ddot{a}$ 'like', the first person singular ending $-n$, the adverb enemmän 'more', the stem of the noun talvi 'winter', and the elative ending -sta. In other words, the meaning of the construction does not build up as the parts are strung together, but the meaning lies in the ensemble of the parts.

$\begin{array}{ll}\text { Tykkää-n enemmän } & \text { talve-sta. } \\ \text { Like-1S G more } & \text { winter-E L A T } \\ \text { 'I like winter more' } & \end{array}$

When L2 learners use the constructions, the constructions may exhibit different kinds of deviations from native-speaker conventions (see example (2) for the tykätä 'like' construction). Therefore, in this study, we have slightly extended Goldberg's (2006) definition of a construction - a conventionalized pairing of form and function - to include the L2 learners' emergent form-meaning mappings, which may not yet seem conventional from the viewpoint of L1 speakers or proficient language users. If the form of the learner language construction resembles the form of the conventionalized construction, the link between the form and function in the learner's construction remains clear and the construction is hence understandable (compare examples (1) and (2)). Moreover, it should be pointed out that learner language constructions that are not frequently occurring - a characteristic of a construction presented by Goldberg - are also included in the analysis, because the learner language constructions are often transient.

$\begin{array}{ll}\text { Tykkää-n enemmän } & \text { *talvi } \\ \text { Like-1s G more } & \text { *winter(N O M ) } \\ \text { 'I like winter more' } & \end{array}$

In the current study, all utterances with the haluta and tykätä construction were selected for analysis. The number of utterances for each participant is shown in Table 3.

The haluta and tykätä verbs, like any other verb in Finnish, agree with the subject (see examples (3) and (4) for the first and second person singular forms). Finnish verbs are conjugated in four tenses and in four moods (VISK $\$ 1523$, $\S 111)$. Negation is marked with the negative ei (see examples (5) and (6)) (VISK §108).

[2] This phrasing should not be construed as claiming that the word tykätä itself is a construction; when referring to, e.g., 'the tykätä construction' we are referring to a multiword evaluative learner construction in which the word tykätä carries the main evaluative semantic load. Whether a single word is a construction or not is subject to debate; compare Goldberg's (2006, p. 18) proposal that "it's constructions all the way down”, i.e., from morphemes and words to abstract syntactic patters $(2006$, p. 5) to the proposal in SBCG (Sign-Based Construction Grammar; Sag, 2012) that words are not constructions; instead, constructions involve words. Resolving this debate lies outside the scope of this paper dealing only with multiword constructions. 
T A B LE 3. Number of utterances with haluta 'want' and tykätä 'like'

\begin{tabular}{lll}
\hline & haluta 'want' & tykätä 'like' \\
\hline Lena & 49 & 34 \\
Alvaro & 36 & 26 \\
Khadiza & 43 & 33 \\
Jungo & 34 & 35 \\
\hline
\end{tabular}

Both the haluta and tykätä constructions can take as complement an NP or an NFC. For the haluta construction, the form of the noun phrase within the construction depends on the context: most frequently the complement is in either the partitive or the genitive case. The $t y k a ̈ t a ̈$ construction requires the elative form of the noun phrase, which is marked with the ending -stA (see example (5)). For both constructions, the verb within the verbal phrase is in the infinitive. The haluta construction can also have a subclausal complement. Examples (3-6) show the NP and NFC complements for both constructions. The first row stands for the schema of the construction, the second row is the actual construction in Finnish, the third row is the glossing (see 'Appendix') and the fourth row is the English translation.

(3) [Haluta + NP]
Halua-n
kahvi-a.
Want-1s G coffee-P A R

'I want coffee'

(4) [HALUTA + NFC]

$\begin{array}{lll}\text { Halua-t } & \text { matkusta-a } & \text { Saksa-an. } \\ \text { Want-2S } & \text { travel-I NF } & \text { Germany-I L L } \\ \text { 'I want to travel to Germany' } & \end{array}$

(5) $\quad[$ т Үкёт $\ddot{A}+\mathrm{NP}]$

E- $n \quad$ tykkää kahvi-sta.

NEG-1SG like coffee-ELAT

'I don't like coffee'

(6) $[$ T Y К $̈$ T $\ddot{A}+\mathrm{NFC}]$

$\begin{array}{llll}E-t & \text { tykkää } & \text { matkusta-a } & \text { Saksa-an. } \\ \text { NEG-2SG } & \text { like } & \text { travel-IN F } & \text { Germany-I LL }\end{array}$

'You don't like to travel to Germany'

\subsection{ANALYTIC PROCEDURES}

Because our interest was in finding out whether our participants' constructions develop from lexically specific to productive patterns, we calculated the number of different forms of haluta and tykätä and the number of different types of complements (NPs, NFCs, and subclauses). We also calculated how many 
different NPs, NFCs, and subclauses were used. Non-target-like forms were included in the count. Based on these numbers, the learners' constructions were put on a continuum from lexically specific to productive. Productivity is a relative notion here, and no claim about absolute productivity or schematicity is made.

Table 4 shows the continuum between lexically fully fixed constructions and highly variable, schematic constructions. For the purposes of this paper, we will define four types of constructions along this continuum. An example of a fully fixed expression is Haluan matkustaa Saksaan 'I want to travel to Germany', as it occurs repeatedly in exactly the same form without an open slot. In this paper, these expressions are called 'lexically specific, formulaic expressions'. Haluan matkustaa + NP 'I want to travel + NP', on the other hand, is an example of what we call a 'mostly formulaic expression' (the term corresponds to Eskildsen's (2008) term 'partially fixed, partially schematic utterance schema'). These expressions have one variable part (i.e., new lexical material is used compared to the earlier use), i.e., the construction has an open slot. Constructions like Haluan + NFC have more than one open slot if the NFC has variable parts, and they are called 'semi-schematic, semi-abstract patterns' in this paper. H A L U T A + NFC is a 'fully schematic, abstract pattern' if the verb is used in various forms with different realizations of non-finite clauses and these expressions are highly variable and productive.

Thus in this study, productivity is defined based purely on the variability of the slots within the construction. The productivity of our learners' constructions is not compared to native-like productivity, but a change in productivity is seen as a change relative to the learners' earlier use of the constructions. However, as more proficient language use is characterized by increased variability and flexibility, an increase in productivity can be seen as more proficient language use.

\section{Results}

In this section, the four learners' developmental trajectories of the haluta 'want' and tykätä 'like' constructions are described by means of representative examples. Each learner will be reported on separately, first regarding the haluta construction and then the tykätä construction.

\subsection{LENA}

\subsubsection{Haluta}

With the haluta construction, Lena initially (weeks 3-5) uses mostly formulaic expressions (see Table 5). The formulaic part in the construction concerns the form of haluta itself and the verb within the non-finite clause. Regarding haluta, Lena uses the first person singular conditional (haluaisin, with little 
T A B LE 4. Continuum between lexically specific and productive constructions, where the NP and NFC are open variable slots

\begin{tabular}{|c|c|c|c|c|}
\hline Example & $\begin{array}{l}\text { Haluan matkustaa Saksaan } \\
\text { 'I want to travel to } \\
\text { Germany' }\end{array}$ & $\begin{array}{l}\text { Haluan matkustaa }+\mathrm{NP} \\
\text { 'I want to travel }+\mathrm{NP} \text { ' }\end{array}$ & $\begin{array}{l}\text { Haluan + NFC } \\
\text { 'I want + NFC' }\end{array}$ & $\begin{array}{l}\text { HALUTA + NFC } \\
\text { WANT + NFC }\end{array}$ \\
\hline $\begin{array}{l}\text { Type of } \\
\text { construction }\end{array}$ & $\begin{array}{l}\text { Lexically specific, } \\
\text { formulaic expression }\end{array}$ & Mostly formulaic expression & $\begin{array}{l}\text { Semi-schematic, } \\
\text { semi-abstract pattern }\end{array}$ & $\begin{array}{l}\text { Fully schematic, } \\
\text { abstract pattern }\end{array}$ \\
\hline $\begin{array}{l}\text { Fixedness of } \\
\text { the construction }\end{array}$ & Fully fixed & $\begin{array}{l}\text { Partially variable: construction } \\
\text { has one open slot }\end{array}$ & $\begin{array}{l}\text { Semi-variable: construction } \\
\text { has more open slots }\end{array}$ & Highly variable \\
\hline $\begin{array}{l}\text { Degree of } \\
\text { productivity }\end{array}$ & Not productive & & & Highly productive \\
\hline
\end{tabular}


T A B LE 5. Lena's initial use of the haluta construction

\begin{tabular}{|c|c|c|c|}
\hline Utt. no. ${ }^{3}$ & HALUTA & $\mathrm{NFC}$ & \\
\hline & & Verb & NP \\
\hline 3.1 & $\begin{array}{l}\text { *Haillo-ia-ni } \\
\text { *Want-C O N D -1s G } \\
\text { intended meaning: } \\
\text { Halua-isi-n } \\
\text { Want-C O N D-1s G }\end{array}$ & $\begin{array}{l}\text { *matkest- } a \\
\text { *travel-I N F }\end{array}$ & $\begin{array}{l}\text { Lappi-in, } \quad \text { *Hankasalmie-lle ja Oulu-un. } \\
\text { Lapland-I L L, *Hankasalmi-A L L and Oulu-A L L }\end{array}$ \\
\hline 4.1 & Halua-isi-n & matkusta-a & Fyväskylä-stä Saksa-an. \\
\hline 4.2 & $\begin{array}{l}\text { Want-C OND }-1 \mathrm{~s} \mathrm{G} \\
\mathcal{F} a \text { halua-isi-n } \\
\text { And want-COND-1s G }\end{array}$ & $\begin{array}{l}\text { travel-I N F } \\
\text { matkusta- } a \\
\text { travel-IN F }\end{array}$ & $\begin{array}{l}\text { Jyväskylä-E L A Germany-I L L } \\
\text { lentokonee-lla. }\end{array}$ \\
\hline 4.3 & $\begin{array}{l}\text { And want-C O N D -1S G } \\
\text { Halua-isi-n } \\
\text { Want-C O N D - } 1 \mathrm{~S} \mathrm{G}\end{array}$ & travel-INF & $\begin{array}{l}\text { plane-ADE } \\
\text { Saksa-an ja myös Lappi-in ja Tamperee-lle. } \\
\text { Germany-I L L and also Lapland-I L L and Tampere-A L L }\end{array}$ \\
\hline 4.4 & $\begin{array}{l}\text { Mih-in halua-isi- } t \\
\text { Where-I L L want-COND-2S G }\end{array}$ & $\begin{array}{l}\text { matkusta-a? } \\
\text { travel-I N F }\end{array}$ & \\
\hline 5.1 & $\begin{array}{l}\text { Halua-isi- } n \\
\text { Want-C OND-1s G }\end{array}$ & $\begin{array}{l}\text { *matkakust-a } \\
\text { *travel-I N F }\end{array}$ & $\begin{array}{l}\text { *Venäjä-än, ja Suome-ssa Lappi-in, } \quad \text { Hankasalme-lle, } \\
\text { *Russia-I L L, and Finland-I N E Lapland-I L L, Hankasalmi-A L L, } \\
\text { *Oulu ja *Helsingi-in. } \\
\text { *Oulu and *Helsinki-I L L }\end{array}$ \\
\hline
\end{tabular}

${ }^{3}$ This column indicates the utterance number; for example, 3.1 means that the utterance was produced in week 3 and is the first utterance with the verb haluta. 
T A B LE 6. Lena's use of the haluta construction in weeks 6-11

\begin{tabular}{|c|c|c|c|}
\hline \multirow[t]{2}{*}{ Utt. no. } & \multirow[t]{2}{*}{ H A L U T A } & \multicolumn{2}{|l|}{$\mathrm{NFC}$} \\
\hline & & Verb & Sub clause / NP \\
\hline 6.1 & $\begin{array}{l}\text { Halua-isi- } n \text {, } \\
\text { Want-C O N - } 1 \mathrm{~s} \mathrm{G}\end{array}$ & $\begin{array}{l}\text { sano- } a \\
\text { say-I N F }\end{array}$ & $\begin{array}{l}e-n \quad \text { tule syntymäpäivä. } \\
\text { NEG }-1 \mathrm{~S} \mathrm{G} \text { come birthday }\end{array}$ \\
\hline 7.1 & $\begin{array}{l}\text { Fa Marja halua-isi } \\
\text { and Marja want-C OND }(3 \mathrm{~s} G)\end{array}$ & $\begin{array}{l}\text { oppi-a } \\
\text { learn-IN F }\end{array}$ & $\begin{array}{ll}\text { englanni-n } & * \text { *ieli. } \\
\text { English-G EN } & * \text { language }\end{array}$ \\
\hline 7.2 & $\begin{array}{l}\text { ja haluaa } \\
\text { and } \operatorname{want}\left(3 \mathrm{SG}_{\mathrm{G}}\right)\end{array}$ & $\begin{array}{l}\text { *osa-ta } \\
\text { *know-I N F }\end{array}$ & $\begin{array}{l}\text { jäätelö-t. } \\
\text { ice.cream-P L }\end{array}$ \\
\hline 9.1 & $\begin{array}{l}\text { Halua-n myös } \\
\text { Want-1s G also }\end{array}$ & $\begin{array}{l}\text { kirjoitta- } a \\
\text { write-I N F }\end{array}$ & $\begin{array}{l}\text { blogi-ssa } \\
\text { blog-I NE }\end{array}$ \\
\hline 10.1 & $\begin{array}{l}\text { Mitä sä halua-t } \\
\text { What you want-2SG }\end{array}$ & $\begin{array}{l}\text { kysy- ̈a? } \\
\text { ask-INF }\end{array}$ & \\
\hline 11.1 & $\begin{array}{l}\text { Halua-isi-n } \\
\text { Want-C OND -1s G }\end{array}$ & $\begin{array}{l}m e n-n \ddot{a} \\
\text { go-I N F }\end{array}$ & $\begin{array}{l}\text { *Suomii-in } \\
\text { *Finland-I L L }\end{array}$ \\
\hline
\end{tabular}

variation in orthographic form in week 1) in five of the six utterances, and the second person singular conditional (haluaisit) in another utterance; regarding the verb phrase, matkustaa 'to travel' (also with little variation in orthographic form) is used in five and intended in the remaining one of the six utterances. The variable part concerns the noun phrase within the non-finite clause (see the fourth column of Table 5). Hence, Lena's haluta construction starts with the pattern [haluaisin matkustaa $+\mathrm{NP}$ ], which has one open slot.

In week 6, Lena for the first time combines haluta with a verb other than matkustaa 'to travel', but still uses the first person singular conditional form of haluta. In the following weeks, new forms of the haluta verb are combined with different non-finite clauses (see Table 6). It therefore seems that Lena has started to develop a more abstract construction and is moving toward a schematic [H A L U T A + NFC] pattern.

With time, Lena's haluta construction becomes ever more productive. Towards the end of the period of observation (weeks 24-36), the construction exhibits so much variability in terms of different forms of haluta (in total 8 different forms) and of its complements (in total 13 different verbs in non-finite clauses) that the [H A L U T A + NFC] pattern seems to have become productive.

Apart from occurring with a non-finite clause, haluta may also directly be followed by a noun phrase. The development of a [H A L U T A NP] pattern starts somewhat later than the development of the [H A L U T A + NFC] pattern, and seems to be based on it, and the data are more restricted: Lena uses a noun phrase as a complement only four times (see Table 7) and in three of the instances (weeks 9,11, and 26), a non-finite clause would be required to convey the intended meaning. These complements could therefore be categorized as 
TAB LE 7. Lena's haluta construction with a noun phrase complement

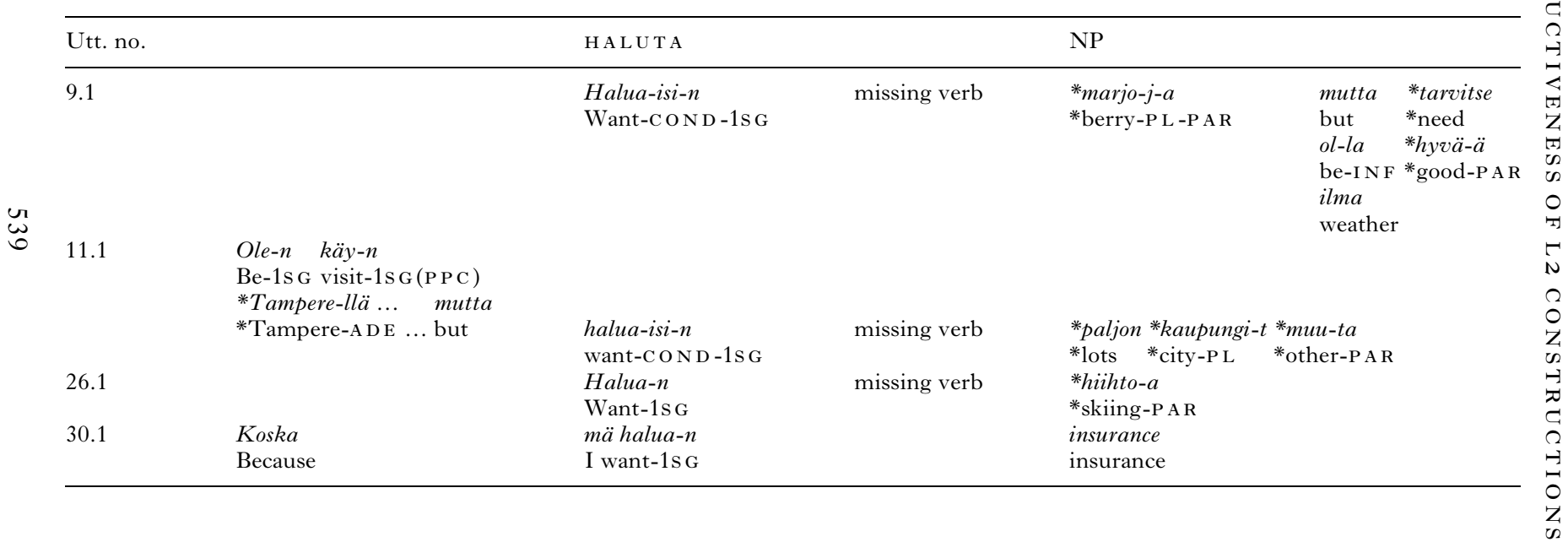


T A B LE 8. Examples of Lena's initial use of the tykätä construction

\begin{tabular}{|c|c|c|}
\hline Utt. no. & T Y K Ä T $\ddot{A}$ & NP \\
\hline 3.1 & $\begin{array}{l}E i \quad * t y k k a \\
\text { NEG(3SG) } * \text { *like } \\
\text { intended meaning: } \\
E-n \text { tykkää } \\
\text { NEG-1SG like }\end{array}$ & $\begin{array}{l}\text { *kahvi-a-st } \\
\text { *coffee-PAR-ELAT }\end{array}$ \\
\hline 4.1 & $\begin{array}{l}\text { Tykkää-t-kö } \\
\text { Like-2s G -Q }\end{array}$ & $\begin{array}{l}\text { pitsa-sta? } \\
\text { pizza-E L A }\end{array}$ \\
\hline 4.2 & $\begin{array}{l}\text { Tykkä̈̈- } n \\
\text { Like-1s G }\end{array}$ & $\begin{array}{l}\text { tomaati-sta. } \\
\text { tomato-E L A }\end{array}$ \\
\hline 4.3 & 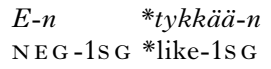 & $\begin{array}{l}\text { *musika-sta } \\
\text { *music-E L A }\end{array}$ \\
\hline
\end{tabular}

non-finite clauses in which the verb is omitted in a non-target-like way, i.e., their target-like form would still conform to the [HALUTA + NFC] pattern that Lena has already developed at that point. These non-target-like forms seem to represent a new step in Lena's development of the use of haluta: while earlier inaccuracies concerned the form (phonology or orthography) only, omitting a verb relates to the abstract schema and may therefore be regarded as a different kind of non-target-like use. Lena is getting more productive, and seems to use the established [HALUTA + NFC] pattern to develop towards a [H A LU T A + NP] pattern.

Continuity with her earlier development is also apparent in her reuse of the frequent first person singular conditional form of haluta in weeks 9 and 11 (see Table 7). It is only in week 30 that Lena finally combines haluta with an NP in a target-like way. This use shows creativity: in the multilingual construction koska mä haluan insurance 'because I want insurance', Lena's use of a non-Finnish word within the construction demonstrates that she is aware of the inner structure of the construction and is not simply repeating something she has picked up from her exposure. Therefore, it could be argued that at this point Lena has finally arrived at a productive pattern of $[$ HALUTA + NP].

\subsubsection{T Y K $\ddot{\mathrm{A}} \mathrm{T} \ddot{\mathrm{A}}$}

Lena's initial use of the tykätä construction is different from that of her haluta construction. Lena's utterances are more variable and the construction is semischematic right from the start (see representative examples in Table 8). In the first two weeks (weeks 3-4, 9 utterances), Lena uses three forms of tykätä (with some variation in accuracy): tykkään 'I like' (3 times), en tykkää 'I don't like' 
T A B LE 9. Examples of Lena's [tykkään + NFC] pattern in weeks 5-10

\begin{tabular}{|c|c|c|}
\hline & T Y K Ä T Ä & $\mathrm{NFC}$ \\
\hline 5.1 & $\begin{array}{l}\text { Tykkä̈̈-n } \\
\text { Like-1s G }\end{array}$ & 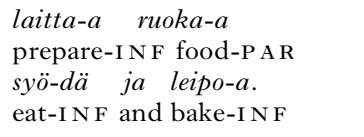 \\
\hline 8.1 & $\begin{array}{l}\text { Tykkä̈̈-n } \\
\text { Like-1s G }\end{array}$ & $\begin{array}{l}\text { laitta- } a \text { ruoka- } a \\
\text { prepare-IN F food-P AR } \\
j a \text { matkusta- } a \text {. } \\
\text { and travel-I N F }\end{array}$ \\
\hline 9.1 & $\begin{array}{l}* T y k k \ddot{a}-n \\
* \text { Like-1s G }\end{array}$ & $\begin{array}{ll}\text { laula-a } & \text { kuoro-ssa. } \\
\text { sing-I N F } & \text { choir-I NE }\end{array}$ \\
\hline 10.1 & $\begin{array}{l}\text { Mä tykkä̈̈-n } \\
\mathrm{I} \quad \text { like-1s G }\end{array}$ & $\begin{array}{l}\text { *laihta- } a \text { ruoka- } a \text {, } \\
\text { * prepare-I N F food-P A R, } \\
\text { matkusta- } a \text {, } \\
\text { travel-I N F, } \\
\text { neulo- } a \text { ja luke- } a \text {. } \\
\text { knit-I N F and read-I N F }\end{array}$ \\
\hline 10.2 & $\begin{array}{l}\text { Tykkä̈̈-n } \\
\text { Like-1s G }\end{array}$ & $\begin{array}{l}\text { to pick marjo- } j-a \\
\text { to pick berry-P L-P A R }\end{array}$ \\
\hline 10.3 & $\begin{array}{l}\mathcal{F a} \text { tykkä̈̈- } n \text { myös } \\
\text { And like-1s G also }\end{array}$ & $\begin{array}{ll}\text { oppi-a } \quad \text { kiel- } i-\ddot{a} . \\
\text { learn-I N F language-P L-P A R }\end{array}$ \\
\hline
\end{tabular}

(4 times), and tykkäätkö 'do you like' (twice). She uses only noun phrases as complements but their use is relatively variable: in these 9 utterances, 15 different noun phrases are used. Hence, there seems to be an open slot for a noun phrase within the construction right from the start. Lena's tykätä construction therefore starts with the semi-schematic patterns $[t y k k \ddot{a} \ddot{a} n+\mathrm{NP}]$, [en tykkäa + $\mathrm{NP}]$, and [tykkäätk $\ddot{o}+\mathrm{NP}]$.

The tykätä construction requires the elative form of the noun phrase. In weeks 3-4, Lena uses the required elative ending -sta (week 3: * $-s t$ ) in virtually all cases and seems to use top-down processes when constructing the forms. In week 3 , the elative ending is added to a partitive form kahvia, instead of to the stem kahvi 'coffee' (see 3.1 in Table 8). Mass nouns, such as kahvi 'coffee', are often used in the partitive, and it seems that Lena uses the frequently occurring partitive kahvia as a stem, and used a top-down process based on explicit knowledge when adding the elative ending to that form. In other words, Lena seems to possess a generalization for the use of the elative ending: this utterance provides evidence that the $t y k a ̈ t a ̈$ construction is not a rote-learned unit picked up from exposure, but that Lena seems to know that it consists of different parts. Other utterances produced in week 4 provide further support for this interpretation of a noun phrase complement consisting of a stem and the elative ending sta. Besides using the noun phrase pitsa 'pizza' within the tykätä construction, 
Lena uses pitsa within two other constructions as well, and in these constructions, pitsa is declined in a case other than the elative case (see examples (7-9)).

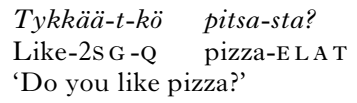

(8) Mene-t-kö pitsa-lle illa-lla? Go-2s G-Q pizza-ALL night-ALL 'Do you go for a pizza tonight?'

(9) Mun lempiruoka o-n pitsa. My favorite.food be-3sg pizza 'My favorite food is pizza.'

In week 5, when Lena begins to use non-finite clauses within the construction, she immediately uses 3 different non-finite clauses as a complement (see Table 9 for representative examples). The verbal phrase laittaa ruokaa 'prepare food' is repeated in weeks 8 and 10, and the verb matkustaa 'travel' is used twice, but otherwise non-finite clauses are used variably. It therefore seems that a non-finite clause slot opens up quite quickly. The multilingual construction tykkään to pick marjoja 'I like to pick berries' (10.2) and the particle myös 'also' (10.3) point to a more productive pattern, too. However, a nonfinite clause is only used with the first person singular form, so it seems that instead of having a highly schematic pattern [т Y к ̈̈ T $\ddot{A}+\mathrm{NFC}$, Lena has a semi-schematic pattern [tykkään + NFC].

Towards the end of the study (weeks 10-34), Lena uses 5 different forms of tykätä and 8 different noun phrases within the construction. Besides one noun phrase, kahvi 'coffee', the noun phrases used at the end of the period of observation are different from the noun phrases used at the beginning, and therefore Lena's [T Y K ̈̈ T $\ddot{A}+\mathrm{NP}$ ] pattern seems to have become productive. Non-finite clauses are only used with the first person singular form, so Lena seems to have developed a semi-schematic pattern of [tykkään $+\mathrm{NFC}]$.

\subsection{J U G O}

\subsubsection{Haluta}

Jungo's initial use of the haluta construction is similar to that of Lena's: Jungo too relies on the first person singular conditional form at the beginning. In weeks 4-14, haluaisin 'I would like to' is used four times and its negation is used once (see Table 10). However, compared to Lena, the complements within Jungo's haluta construction are more variable; in five utterances, five different non-finite clauses are used. Moreover, in week 8 , the particle myös 'also' is used, pointing to a more productive pattern. While Lena's haluta construction starts with a mostly formulaic pattern [haluaisin matkustaa $+\mathrm{NP}$ ], Jungo starts with a somewhat more productive, semi-schematic pattern of [haluaisin $+\mathrm{NFC}$ ]. 
T A B LE 10. Fungo's initial use of the haluta construction

\begin{tabular}{|c|c|c|c|c|}
\hline Utt. no. & & H A L U T A & NFC & \\
\hline & & & Verb & NP \\
\hline $4.1^{4}$ & \multirow{9}{*}{$\begin{array}{r}\text { Main clause } j a \\
\text { and }\end{array}$} & mä halua-isi-n & matkusta-a & \\
\hline 7.1 & & $\begin{array}{l}\text { I } \quad \text { want-C OND-1S G } \\
e-n \quad \text { halua-isi }\end{array}$ & $\begin{array}{l}\text { travel-I N F } \\
\text { opiskel-la }\end{array}$ & $\begin{array}{l}\text { Helsinki-I L L, Lapland-I L L and *Tampere } \\
\text { suome- } a\end{array}$ \\
\hline & & NEG -1S G want-C O N D & study-I N F & Finnish-P A R \\
\hline \multirow[t]{3}{*}{8.1} & & $\begin{array}{l}\text { mä myös } \\
\mathrm{I} \quad \text { also }\end{array}$ & & \\
\hline & & halua-isi-n & ol-la & opettaja \\
\hline & & want-C O ND-1s G & be-INF & teacher \\
\hline 10.1 & & mä halua-isi-n & $s y \ddot{o}-d \ddot{a}$ & *kiinalaise-sta *luoka \\
\hline 14.1 & & $\begin{array}{l}\text { 1 want-COND-1SG } \\
\text { mä halua-isi-n }\end{array}$ & $\begin{array}{l}\text { *at-1N F } \\
\text { * } u h u\end{array}$ & suome- $a$. \\
\hline & & I want-C OND-1s G & *speak & Finnish-P A R \\
\hline
\end{tabular}


TABLE 11. Fungo's [HALUTA + NP] pattern

\begin{tabular}{llll}
\hline Utt. no. & & H ALUTA & $\mathrm{NP}$ \\
\hline 23.1 & $\begin{array}{l}\text { he voi-vat *aatta- } a \\
\text { they can-3P L *dress-I N F }\end{array}$ & $\begin{array}{l}\text { mikä } \\
\text { what }\end{array}$ \\
& & $\begin{array}{l}\text { he halua-vat } \\
\text { they want-3P }\end{array}$ & \\
34.1 & heskus & halua-vat & ihmise-t joka voi aja-a \\
& sometimes & &
\end{tabular}

After the exclusive use of the conditional form at the start, Jungo moves towards a highly productive pattern of [H A L U T A $+\mathrm{NFC}]$. At the end of the period of observation (weeks 26-36), 8 different forms of the haluta verb, and 12 different non-finite clauses are used within the [H A L U T A + NFC] pattern.

A noun phrase is used twice as a complement, both times with the third person plural form (see Table 11). Because of this use only with the third person plural form, on the basis of the data available we might assume that Jungo has a semi-productive pattern [he haluavat $+\mathrm{NP}$ ] 'they want $+\mathrm{NP}$ '. The assumption of an open slot for a noun phrase is justified by the fact that both instances are not fully target-like, showing that they are not rote-learned.

Jungo is the only learner who uses a subclause as a complement of haluta (see example 10). This structure is non-target-like because the linking word että 'that' is missing.

$$
\begin{array}{lllllll}
\text { Hänen } & \text { tyttöystävä } & \text { ei } & \text { *halua-t } & \text { hän } & \text { *pelaa-n } & \text { peli } \\
\text { His } & \text { girlfriend } & \text { NEG(3SG }) & \text { *want-2SG } & \text { he } & \text { *play-1SG } & \text { game } \\
\text { 'His girlfriend doesn't want him to play a game' } & & &
\end{array}
$$

\subsubsection{Tykätä}

Jungo's initial use of the tykätä construction resembles that of his haluta construction. His use of tykätä also starts with two forms: tykkään 'I like' and tykkä̈̈tk ' 'do you like'. Of these, tykkään is used more frequently ( 8 out of 11 utterances, weeks $2-5$ ). In weeks $2-3$, Jungo uses only noun phrases as complements. These are variable, pointing to an open slot for a noun phrase right from the start. In other words, Jungo begins with the semi-schematic patterns [tykkään $+\mathrm{NP}]$ and [tykkäätkö $+\mathrm{NP}]$.

When constructing noun phrases, Jungo seems to use a top-down process. This is visible when a generalization, an explicitly learned pattern, tykätä + NP $+s t a$, is applied. In week 3 , Jungo writes the -sta ending separately from the noun phrases. This particular way of spelling indicates that the noun phrase and its ending are not a unit for him but rather are two separate parts. Also, some non-target-like forms show that some expressions are not picked up as 
chunks but derive from a top-down process, for example, when Jungo adds a suffix to the stem of the noun without applying the required changes in the stem. This results in the non-target-like forms shown in utterances 3.2 and 7.1 in Table 12 (target-like forms: englannista, suomalaisesta, kiinalaisesta, venäläisestä). In the noun phrases *futistasta 'football' (2.3, Table 12) and *ruokaasta 'food' (3.2, Table 12), Jungo used frequently occurring partitive forms (futista and ruokaa) as a stem to which the elative ending -sta is attached. This is similar to Lena's production of the *kahviast 'coffee' form. In these expressions, both top-down and bottom-up processes are used: partitive forms are picked up from exposure and pasted into the NP slot within the explicitly learned pattern.

Towards the end of the period of observation (weeks 10-34), Jungo uses 5 different forms of the tykätä verb, and 17 noun phrases are used as complements. He therefore seems to have developed a highly schematic pattern [T Y K ̈̈ T $\ddot{A}+\mathrm{NP}]$.

Regarding the [T Y К $\ddot{\text { T }} \ddot{\mathrm{A}}+\mathrm{NFC}$ ] pattern, it seems that Jungo uses nominal forms of verbs (a type of NP) to some extent as stepping-stones towards the use of non-finite clauses. The first nominal complements are used in week 3 (see Table 15), and a non-finite clause is used for the first time in week 4 (see Table 13). A nominal form ruuanlaitto 'cooking' (5.1, Table 13) is used before the non-finite clause laittaa ruokaa 'to cook' (10.2) and similarly, the nominal form syöminen 'eating' (32.1) is used before the non-finite clause syödä ruokaa 'eat food' (33.1).

Jungo uses non-finite clauses as complements only with the first person singular form tykkään (6 utterances, see Table 13). Hence, like Lena, Jungo seems to develop a semi-schematic [tykkään $+\mathrm{NFC}]$ pattern, but the data do not provide evidence for a fully schematic [T Y K ̈̈ T $\ddot{A}+\mathrm{NFC}$ ] pattern. In two utterances (16.2 and 20.1), it is unclear whether the complement is a noun phrase or an NFC, because the forms of the complements are non-target-like.

\subsection{ALVARO}

\subsubsection{Haluta}

In contrast to Lena's and Jungo's initial use of haluta, Alvaro uses a more productive pattern right from the start. Both the haluta itself and its complements show variation in the first three weeks: he uses five different forms of haluta (see Table 14), and six different non-finite clauses and one noun phrase as complements (see representative examples in Table 14).

Further evidence for a productive pattern is provided by the use of a nontarget-like form *on haluaa 'is want' (see 6.1, Table 14), and the use of some non-target-like past tense forms. They clearly show that Alvaro is breaking up 
T A B LE 12. Fungo's initial use of the tykätä construction

\begin{tabular}{|c|c|c|}
\hline Utt. no. & TYKÄT Ä & NP \\
\hline \multirow[t]{2}{*}{2.1} & Mä tykkä̈̈-n & *Englanti-sta \\
\hline & I like-1s G & *English-E L A T \\
\hline \multirow[t]{2}{*}{2.2} & Tykkää-t-kö & *futis-ta-sta? \\
\hline & Like-2s G -Q & football-P A R-E L A T \\
\hline 3.2 & Minä mÿ̈s tykkä̈̈-n & $\begin{array}{l}\text { koira-sta, } \\
\text { dog-Eiinalainen-sta *ruokaa-sta ja * *uomalainen-sta }\end{array}$ \\
\hline 5.2 & Minä tykkä̈̈̈-n myös & $\begin{array}{llll}\text { kiinalaise-sta } & \text { ruua-sta, } & \text { suomalaise-sta } & \text { runa-sta ja kesä-stä } \\
\text { Chinese-ELAT food-ELAT, } & \text { Finnish-ELAT food-ELAT and summer-E LAT T }\end{array}$ \\
\hline \multirow[t]{4}{*}{7.1} & Suomalainen ei & \\
\hline & Finnish NEG(3SG) & \\
\hline & tykkää & *ruostilainensta ja *venäjäläinenstä \\
\hline & like & *Swedish-E L A T and *Russian-E L A T \\
\hline
\end{tabular}


T A B LE 13. Fungo's use of nominal forms of verbs, non-finite clauses, and intended non-finite clauses as complements

\begin{tabular}{|c|c|c|c|}
\hline Utt. no. & T Y K $\ddot{A} T \ddot{A}$ & $\mathrm{NFC}$ & NP (nominal form of a verb) \\
\hline 3.1 & $\begin{array}{l}\text { Minä tykkä̈̈-n } \\
\mathrm{I} \quad \text { like-1s G }\end{array}$ & & $\begin{array}{l}\text { *uima-sta, } \quad \text { *laula-sta } \quad j a \\
\text { *swimming-E L A T, } \text { *singing-E L A T and } \\
\text { *kirja blogi-sta } \\
\text { *book blog-E L A T }\end{array}$ \\
\hline 4.2 & $\begin{array}{l}m \ddot{a} \text { tykkä̈̈-n } \\
\mathrm{I} \quad \text { like-1s G }\end{array}$ & $\begin{array}{ll}k a t s o-a & t v-t \ddot{a} \\
\text { watch-I N F } & \text { tv-P A R }\end{array}$ & \\
\hline 5.1 & $\begin{array}{l}\text { Minä tykkä̈̈-n } \\
\mathrm{I} \quad \text { like-1s G }\end{array}$ & $\begin{array}{ll} & * \\
* \text { *atkustaja } & * \\
* \text { travel and } & l c\end{array}$ & $\begin{array}{l}\text { *ruualaito-sta, } \\
\text { *cooking-E L A T } \\
\text { laulamise-sta } \\
\text { singing-E L A T }\end{array}$ \\
\hline 10.1 & $\begin{array}{l}m \ddot{a} \text { tykkä̈̈̈- } \\
\mathrm{I} \quad \text { like-1s G }\end{array}$ & $\begin{array}{l}\text { *mene-e metsä-än } \text { Fyväskylä-ssä ja maljasta-a } \\
\text { *go(3s G }) \text { forest-I L L Jyväskylä-I N E and pick.berries- }\end{array}$ & $\begin{array}{l}\text { mustikka ja sieni- } \ddot{a} \\
\text {-I N F blue-berry and mushroom-P L.P A R }\end{array}$ \\
\hline 10.2 & $\begin{array}{l}\text { mä tykkä̈̈-n } \\
\text { I like-1s G }\end{array}$ & $\begin{array}{ll}* \text { *aitto-o } & * \text { luoka } \\
* \text { prepare-I N F } & * \text { food }\end{array}$ & \\
\hline 16.1 & $\begin{array}{l}m \ddot{a} \text { tykkä̈̈- } n \\
\text { I like-1s G }\end{array}$ & 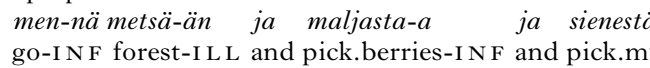 & $\begin{array}{l}t \ddot{a}-\ddot{a} \\
\text { nushrooms-I N F }\end{array}$ \\
\hline 16.2 & $\begin{array}{l}m \ddot{a} e-n \quad t y k k a ̈ a ̈ \\
\mathrm{I} \quad \mathrm{NEG}-1 \mathrm{sG} \text { like }\end{array}$ & & $\begin{array}{l}\text { *matka bussi-lla } \\
\text { *trip bus-ADE }\end{array}$ \\
\hline 20.1 & $\begin{array}{l}\text { hän *tykää } \\
\text { he } * \operatorname{like}(3 \mathrm{SG})\end{array}$ & & $\begin{array}{l}\text { *matku } \\
\text { *trip/*travel }\end{array}$ \\
\hline 32.1 & Ihmiset tykkää-vät & & *syömi-stä \\
\hline 33.1 & $\begin{array}{l}\text { Person-P L like-3P L } \\
\text { minä tykkä̈̈- } n \\
\mathrm{I} \quad \text { like-1s G }\end{array}$ & $\begin{array}{ll}\text { syö-d } \ddot{a} & \text { ruoka-a } \\
\text { eat-I N F } & \text { food-P A R }\end{array}$ & *eating-E L A T \\
\hline
\end{tabular}


T ABLE 14. Examples of Alvaro's initial use of the haluta construction

\begin{tabular}{|c|c|c|c|c|c|}
\hline \multirow[t]{2}{*}{ Utt. no. } & & \multirow[t]{2}{*}{ H A L U T A } & \multicolumn{2}{|l|}{$\mathrm{NFC}$} & \multirow[t]{2}{*}{ NP } \\
\hline & & & Verb & NP & \\
\hline 3.1 & \multirow{7}{*}{$\begin{array}{l}\text { Mitä } \\
\text { What }\end{array}$} & Halua-n & $a s u-a$ & $* t a l-l a$ & \\
\hline & & Want-1s G & live-I N F & *this-A D E & \\
\hline 4.1 & & Halua-t-ko & men-nä & *kahvi-lla & \\
\hline & & want-2s G -Q & go-I N F & *coffee-A D E & \multirow{4}{*}{$\begin{array}{l}k a h v i-a \\
\text { coffee-P A R }\end{array}$} \\
\hline 4.2 & & sä halua-t & juo-da? & & \\
\hline 6.1 & & $\begin{array}{l}*_{0}-n \text { haluaa } * \\
\text { be- } 3 \mathrm{~S} \text { G } \operatorname{want}(3 \mathrm{SG})\end{array}$ & UIHIR-1 T F & & \\
\hline 6.2 & & $\begin{array}{l}\text { Halua-isi-n } \\
\text { want-C OND-1s G }\end{array}$ & $\begin{array}{l}\text { *nukka } \\
\text { *sleep }\end{array}$ & & \\
\hline
\end{tabular}

the haluta verb in an attempt to express new meanings: the grammatical marker of the past tense $-i$ and the personal endings $-m m e$ and $-n$ are added to the stem halua (see examples (11) and (12)). Breaking up the verb like this indicates that Alvaro is aware of the different parts of the construction as well as their functions and, in general, how Finnish verbal inflections function.

*Halua-i-mme

Weeks 13, 18, 34 *Want-PS T -1P L

'We wanted'

(12) *Halua $-i-n$

Week $15 *$ Want-P S T -1s G

'I wanted'

Alvaro's haluta construction becomes even more productive over time. At the end of the period of observation (weeks 19-36), 7 different forms of haluta, and 13 different non-finite clauses are used. For the [H A L U T A + NP] pattern the data are more restricted: during the period of observation only three different noun phrases are used as complements, but they are all used with different forms of haluta. Because every construction with a noun phrase complement is different, it can be argued that this structure is productive as well. Alvaro therefore seems to have developed a productive haluta construction.

\subsubsection{Tykätä}

Like the haluta construction, Alvaro's tykätä construction is relatively variable right from the start in terms of both the forms of tykätä and its complements (see Table 15 for representative examples). However, the tykätä construction starts with fewer forms than haluta: in the first 5 weeks (13 utterances), he uses 
T A B LE 15. Examples of Alvaro's initial use of the tykätä construction

\begin{tabular}{|c|c|c|c|c|}
\hline \multirow[t]{2}{*}{ Utt. no. } & & \multirow[t]{2}{*}{ T Y K $\ddot{A} T \ddot{A}$} & \multicolumn{2}{|l|}{$\mathrm{NFC}$} \\
\hline & & & VERB & NP \\
\hline \multirow{2}{*}{\multicolumn{2}{|c|}{1.1}} & *Tykkä-n & opiskel (la) & *paivaa $($ na) *yliopisto $($ ni) \\
\hline & & *Like-1s G & study & *day *university \\
\hline \multirow{2}{*}{\multicolumn{2}{|c|}{1.2}} & *Tykkä-n & & *kahvi, *lounas, *maito \\
\hline & & *Like-1s G & & *coffee, *lunch, *milk \\
\hline \multirow{2}{*}{\multicolumn{2}{|c|}{2.1}} & *Tukkää-t? & & \\
\hline & & *like-2s G & & \\
\hline \multirow[t]{2}{*}{3.1} & & *Tykkä-n & & *musiikki-sta, elokuv-i-sta ja \\
\hline & & *Like-1s G & & $\begin{array}{l}\text { *music-E L A T, movie-P L-E L A and } \\
\text { *ruoka-lta (*ruoka-sta) } \\
\text { *food-A DE (*food-ELAT) }\end{array}$ \\
\hline \multirow[t]{2}{*}{4.1} & Main clause & $* t y k k a a-t-k o$ & *matkukusta-a? & \\
\hline & & *like-2s G -Q & *travel-I N F & \\
\hline \multirow[t]{2}{*}{4.2} & & *tykkaa-t-ko & & *musiikki-a? \\
\hline & & *like-2s G -Q & & *music-P A R \\
\hline \multirow[t]{2}{*}{4.3} & & Tykkää-n & & *elokuv-i-a. \\
\hline & & Like-1s G & & *movie-P L -P A R \\
\hline \multirow[t]{2}{*}{5.1} & Main clause, mutta but & tykkää-n & *kuunele-sta & *musii paljon \\
\hline & & like-1s G & *listen-E L A T & *music much \\
\hline \multirow[t]{2}{*}{5.2} & & $T y k k \ddot{a} \ddot{a}-n$ & & Pink Floydi-sta \\
\hline & & like-1s G & & Pink Floyd-E LA T \\
\hline
\end{tabular}


three different forms of tykätä: tykkään 'I like' (also *tykkän ${ }^{5}$ ), tykkäätkö 'do you like' (also *tykkaatko ${ }^{6}$ ) and *tukkäät 'you like' (the latter ones used for questions). Tykkään is the most frequently used form (10 of 13 utterances) and therefore the tykätä construction starts quite strongly with the first person singular form. Both non-finite clauses and noun phrases are used already in week 1 , and in the first five weeks a total of 3 different non-finite clauses and 9 different noun phrases are used with both first and second person singular forms. Hence, Alvaro's tykätä construction starts off with the patterns of [tykkään $+\mathrm{NP}]$,

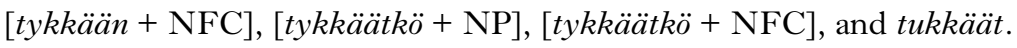

As indicated above, Alvaro's tykätä construction is semi-schematic from the beginning. The utterances produced in weeks 3 and 4 (see 3.1, 4.2, and 4.3, Table 15) provide further evidence for this interpretation. Even though some lexical material (musiikki 'music', elokuvat 'movies') is recycled, no lexical sequence is repeated, indicating that the construction is not a unit for Alvaro but that it rather consists of parts. The noun phrases within the construction are not fixed units either, because both target-like and nontarget-like endings are used with the same nouns. Moreover, in week 3, Alvaro provides two alternatives for the noun phrase ruoka 'food', indicating his knowledge about the use of an ending within the construction. This ending should be the elative, but consonant gradation within the stem is not applied and the form therefore resembles Jungo's englantista noun phrase.

Over time the tykätä construction develops into a more productive pattern: more forms are used and slots for modifiers open up as well, since Alvaro uses the words paljon 'a lot', myös 'also', tosi 'very', and parempi 'better' within the construction. Towards the end of the period of observation (weeks 14-30), the [TYK $\ddot{\text { Tि }}$ A NP] pattern seems to have become productive because 4 different forms of tykätä (3 of them being different than the initial forms of tykätä), and 11 different noun phrases are used. With the [TY К $̈$ т $\ddot{A}+$ $\mathrm{NFC}$ ] pattern, the data are more restricted because Alvaro does not use the [TYк $\ddot{\mathrm{AT}} \ddot{\mathrm{A}}+\mathrm{NFC}]$ pattern after the first weeks. However, in these three utterances, the non-finite clause is always different and the $\mathrm{NFC}$ is used twice with the first person singular and once with the second person singular interrogative form (see Table 15). Therefore, Alvaro's [T Y к ̈̈ т̈ + NFC] cannot be considered as highly productive but it is more abstract than Lena's and Jungo's.

[5] The variability visible in the written forms is disregarded in this analysis as both forms were clearly used to express first person singular.

[6] Initially, Alvaro's pronunciation of back and front vowels was occasionally somewhere between the target-like ä/a, ö/o, and y/u. Again, this minor variability was disregarded when the number of different forms were calculated, e.g., tykkäätkö and tykkaatko were categorized in the same group and considered as the same form. 
4.4. K H A D I Z A

\subsubsection{Haluta}

Khadiza's initial use of the haluta construction is similar to Alvaro's: the construction originates in several forms and the use of complements is quite flexible. In the first five weeks (6 utterances), six different forms of haluta and four different non-finite clauses are used (see Table 16). In the two utterances produced in weeks 7 and 8 the non-finite clauses are almost identical, but in both cases the conjugation of the haluta verb is target-like, pointing to Khadiza's knowledge about the different communicative functions of different parts within the construction. So Khadiza begins with a semi-schematic pattern of the haluta construction.

The productivity of this construction grows over time as some new forms are used and combined with different non-finite clauses. At the end of the period of observation (weeks 34-35), 13 different non-finite clauses are used as complements. However, compared with other learners, Khadiza's haluta construction remains less variable in two respects. First, Khadiza does not use any noun phrases as complements. Second, at the end of the period of observation, Khadiza uses fewer different forms of haluta than other learners (see Table 22). Moreover, at the end of the data collection period, Khadiza is also using lexically relatively fixed units: in week 34, she expresses the meaning 'I want to travel to Bangladesh', with very little variation in form, in total six times.

\subsubsection{Tykätä}

Khadiza's tykätä construction starts with two forms, tykkäätkö 'do you like' and tykkään 'I like', and both noun phrases and non-finite clauses are used as complements from early on with both forms (see Table 17 for representative examples). In other words, Khadiza's tykätä construction starts with the patterns $[$ tykkään $+\mathrm{NP}],[$ tykkään $+\mathrm{NFC}],[$ tykkäätkö $+\mathrm{NP}]$, and $[$ tykkäätkö $+\mathrm{NFC}]$. As with Alvaro, some lexical material is recycled, but no specific lexical string is repeated, showing that the construction is not learned as a chunk, but that some kind of schema has already been developed (see utterances 4.5 and 4.6, and 4.8 and 4.9). The use of the particle myös 'also' implies too that the pattern is to some extent productive.

Towards the end of the period of observation (weeks 14-24), Khadiza's [T Y K ̈̈ T $\ddot{A}+\mathrm{NP}]$ and [T Y K ̈̈ T $\ddot{A}+$ NFC] seem to have become productive. In these last weeks, Khadiza uses 3 different forms of the $t y k a \ddot{t} t \ddot{a}$ verb (2 of them being different than the initial forms), 7 different NPs (all different from the 
T A B LE 16. Khadiza's initial use of the haluta construction

\begin{tabular}{|c|c|c|c|c|}
\hline Utt. no. & & HALUTA & $\mathrm{NFC}$, verb & NFC, NP \\
\hline 4.1 & $\begin{array}{l}\text { Mihin } \\
\text { Where }\end{array}$ & halua-isi-t & matkusta-a & $\begin{array}{l}\text { Suome-ssa? } \\
\text { Finland-INE? }\end{array}$ \\
\hline 5.1 & $\begin{array}{r}\text { Main clause, } k \text { koska } \\
\text { because }\end{array}$ & $\begin{array}{l}\text { he *haluai } \\
\text { they *want }\end{array}$ & & \\
\hline 6.1 & & $\begin{array}{l}\text { Martin halua-isi } \\
\text { Martin want-C OND (3S G) }\end{array}$ & $\begin{array}{l}\text { *ui-ma-a } \\
\text { *swim-3.I N F-I L L }\end{array}$ & \\
\hline 6.2 & & $\begin{array}{l}\text { Martin haluaa } \\
\text { Martin want }(3 \mathrm{SG})\end{array}$ & $\begin{array}{l}\text { osta- } a \\
\text { buy-INF }\end{array}$ & $\begin{array}{l}\text { pitsa-a } \\
\text { pizza-P A R }\end{array}$ \\
\hline 7.1 & $\begin{array}{l}\text { Tulevaisuude-ssa } \\
\text { Future-I NE }\end{array}$ & $\begin{array}{l}\text { han halua-isi } \\
\text { he want-C OND (3SG) }\end{array}$ & $\begin{array}{l}o l-l a \\
\text { be-I N F }\end{array}$ & $\begin{array}{l}\text { opettaja ja ohjelmoija } \\
\text { teacher and coder }\end{array}$ \\
\hline 8.1 & $\begin{array}{l}\text { Tulevaisuude-ssa } \\
\text { Future-I N E }\end{array}$ & $\begin{array}{l}\text { halua-isi-n } \\
\text { want-C O N D -1s G }\end{array}$ & $\begin{array}{l}\text { *ol-lan } \\
\text { *be-I N F }\end{array}$ & $\begin{array}{l}\text { opettaja vai ohjelmoija } \\
\text { teacher or coder }\end{array}$ \\
\hline
\end{tabular}


TAB LE 17. Examples of Khadiza's tykätä construction in weeks 2-5

\begin{tabular}{|c|c|c|c|c|}
\hline & & NFC & & NP \\
\hline Utt. no. & T Y K $\ddot{A} T \ddot{A}$ & Verb & $\mathrm{NP}$ & \\
\hline \multirow[t]{2}{*}{2.1} & tykkää-t-kö & & & *Suomi \\
\hline & like-2s G -Q & & & *Finland \\
\hline \multirow[t]{2}{*}{2.2} & $* t y k k a a-t-k o^{7}$ & & & *ruoka *suomi-n \\
\hline & *like-2s G -Q & & & *food *Finland-G E N \\
\hline \multirow[t]{2}{*}{4.1} & $* t y k k a a-t-k o$ & leikki-a & las-te-n kanssa & \\
\hline & *like-2S G -Q & play-I NF & child-P L-P A R with & \\
\hline \multirow[t]{2}{*}{4.5} & *tykkaa-t-ko & & & liha-sta vai kala-sta \\
\hline & *like-2s G -Q & & & meat-E L A or fish-E LA \\
\hline \multirow[t]{2}{*}{4.6} & mä myös *tykkaa-n & & & liha-sta \\
\hline & I also *like-1s G & & & meat-E L A \\
\hline \multirow[t]{2}{*}{4.7} & *tykkaa-n & & & kala-sta myös *kasvi-sta \\
\hline & *like-1s G & & & fish-E L A also *vegetable-E L A *all-E L A \\
\hline \multirow[t]{2}{*}{4.8} & *tykkaa-t-ko & matkusta-a & *Lampi-in & \\
\hline & *like-2S G -Q & travel-INF & *Lapland-I L L & \\
\hline \multirow[t]{2}{*}{4.9} & $m \ddot{a} m y \ddot{s} *$ *tykkaa-n & matkusta-a & *Lampi-in $\quad$ bussi-lla & \\
\hline & I also $*$ like- $1 \mathrm{~s} \mathrm{G}$ & travel-I N F & *Lapland-I L L bus-A DE & \\
\hline \multirow[t]{2}{*}{5.1} & $M \ddot{a} * t y k k a-n$ & laitta- $a$ & *ruoka & \\
\hline & I * like-1s G & prepare-I N F & $*$ food & \\
\hline
\end{tabular}

${ }^{7}$ Similarly to Alvaro, also Khadiza's pronunciation of back and front vowels was occasionally somewhere between the target-like ä/a, ö/o, and y/u. This minor variability was disregarded when the number of different forms were calculated. 
TAB LE 18. All learners' initial use of the haluta construction

\begin{tabular}{|c|c|c|c|c|c|}
\hline \multirow{2}{*}{$\begin{array}{l}\text { Learner } \\
\text { (weeks, } \\
\text { number of } \\
\text { utterances) }\end{array}$} & \multirow{2}{*}{$\begin{array}{l}\text { Number } \\
\text { of forms } \\
\text { of haluta }\end{array}$} & \multirow{2}{*}{$\begin{array}{l}\text { NFC, } \\
\text { number } \\
\text { of verbs }\end{array}$} & \multirow[b]{2}{*}{$\begin{array}{l}\text { Number } \\
\text { of NPs }\end{array}$} & \multicolumn{2}{|c|}{ Degree of productivity } \\
\hline & & & & $\begin{array}{l}\text { Haluta } \\
+ \text { NFC }\end{array}$ & $\begin{array}{l}\text { Haluta } \\
+ \text { NP }\end{array}$ \\
\hline Lena $(1-5,6)$ & 2 & 1 & 0 & Mostly formulaic & Not used \\
\hline Jungo $(4-14,5)$ & 2 & 5 & 0 & Semi-schematic & Not used \\
\hline Alvaro $(3-6,7)$ & 5 & 6 & 1 & Highly schematic & Highly schematic \\
\hline Khadiza $(4-8,6)$ & 5 & 4 & 0 & Highly schematic & Not used \\
\hline
\end{tabular}

T A B LE 19. All learners' initial use of the tykätä construction

\begin{tabular}{|c|c|c|c|c|c|}
\hline \multirow{2}{*}{$\begin{array}{l}\text { Learner (weeks, } \\
\text { number of } \\
\text { utterances) }\end{array}$} & \multirow{2}{*}{$\begin{array}{l}\text { No. of } \\
\text { forms of } \\
\text { tykätä }\end{array}$} & \multirow{2}{*}{$\begin{array}{l}\text { NFC, } \\
\text { no. of } \\
\text { verbs }\end{array}$} & \multirow{2}{*}{$\begin{array}{l}\text { No. } \\
\text { of } \\
\text { NPs }\end{array}$} & \multicolumn{2}{|c|}{ Degree of productivity } \\
\hline & & & & Tykätä + NFC & $\begin{array}{l}\text { Tykätä } \\
\text { + NP }\end{array}$ \\
\hline Lena $(3-4,9)$ & 3 & 0 & 15 & Not used & Semi-schematic \\
\hline Jungo $(2-5,11)$ & 2 & 2 & 15 & Semi-schematic & Semi-schematic \\
\hline Alvaro $(1-5,13)$ & 3 & 3 & 10 & Semi-schematic & Semi-schematic \\
\hline Khadiza $(2-4,13)$ & 2 & 3 & 10 & Semi-schematic & Semi- schematic \\
\hline
\end{tabular}

NPs used at the beginning), and 4 different NFCs (2 being different from the initial constructions).

\section{Discussion}

In this study, we aimed to investigate whether the development of the haluta 'want' and tykätä 'like' constructions of four Finnish L2 learners starts with lexically specific expressions and whether these initial constructions develop into more abstract patterns over time.

Our first hypothesis was that learners usually start with lexically specific constructions. This hypothesis is not supported: only Lena's haluta construction is initially mostly formulaic, but other constructions are initially semi- or highly-schematic (see Tables 18 and 19). Table 20 illustrates the full range of constructions used by each learner in the initial phases.

7 Similarly to Alvaro, also Khadiza's pronunciation of back and front vowels was occasionally somewhere between the target-like ä/a, $/ \mathrm{o}$, and $\mathrm{y} / \mathrm{u}$. This minor variability was disregarded when the number of different forms were calculated. 
T A B LE 20. All learners' initial constructions

\begin{tabular}{|c|c|c|c|c|}
\hline & Formulaic & 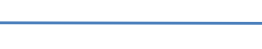 & $\longrightarrow$ & Schematic \\
\hline & Lena's haluta & Jungo's haluta & All learners' tykätä & Alvaro's and Khadiza's haluta \\
\hline Pattern(s) used & $\begin{array}{l}{[\text { haluaisin matkustaa }+\mathrm{NP}]} \\
\text { Mihin haluaisit matkustaa? }\end{array}$ & $\begin{array}{l}{[\text { haluaisin }+\mathrm{NFC}]} \\
\text { En haluaisi opiskella }\end{array}$ & 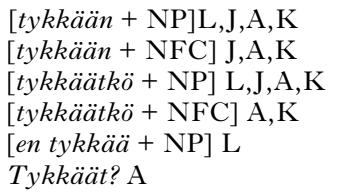 & $\begin{array}{l}{[\text { HALUTA + NFC] }} \\
{[\text { HALUTA + NP] }}\end{array}$ \\
\hline
\end{tabular}


These findings are in line with Roehr-Brackin (2014), who found that a learner can start with both formulaic and more abstract constructions. Lena's and Jungo's use of the rather formulaic haluta construction early on is consistent with Roehr-Brackin's finding regarding the fahren 'drive' construction, which was initially formulaic. Similar formulaic patterns have also been found by Eskildsen (2008, 2018). One possible reason for Lena's and probably also Jungo's initial use of rather formulaic expressions with the first person singular conditional form is that, in week 3, the phrase 'Haluaisin matkustaa + NP' 'I would like to travel + NP' was used frequently in a speaking exercise in class.

Roehr-Brackin (2014) also shows that it is possible for an L2 learner to start with a more productive pattern (the gehen 'go' construction in her study). This 'alternative learning path' (Roehr-Brackin, 2014, p. 771) has not yet been supported in many empirical studies, but semi-schematic patterns similar to the tykätä constructions in this study, and highly schematic, abstract patterns like Alvaro's and Khadiza's haluta, have been found in L2 learners' productions in some earlier studies (besides Roehr-Brackin, 2014, see Eskildsen, 2015). These findings show that the traditional assumption that L2 learners usually start with lexically specific expressions does not hold true. One very good reason could be that adult L2 learners already have an established L1 schematic system and its constructions can be used as templates for L2 expressions (see, e.g., Gustafsson, 2019). Instruction may also play a role, as the tykätä construction was taught in order to point out the communicative functions of its different parts.

Although it is assumed that schemas develop bottom-up, it has been shown that L2 learners also make use of a top-down process (Arndt-Lappe \& Baldus, 2018; Gustafsson, 2019; Roehr-Brackin, 2014). Some non-target-like forms in our data show that the learners' utterances are instantiations of a generalization. For example, Jungo's *englantista 'English' form shows the clear application of an explicitly learned pattern. Jungo's *futistasta 'football' and *ruokaasta 'food', and Lena's *kahviast 'coffee' show how bottom-up and top-down processes are both used. It seems that chunks picked up from exposure (parts of constructions such as juoda kahvia 'to drink coffee', pelata futista 'to play football', laittaa ruokaa 'to prepare food'; i.e., using a bottom-up process) were then pasted into an NP slot within the $t y k a ̈ t a ̈$ construction (using a top-down process).

We also set out to investigate whether the constructions become more abstract over time. Our second hypothesis was that initial constructions develop into more abstract patterns, but that learners will show different levels of abstractness in their constructions at the end of the period of observation. This hypothesis is supported for both constructions. All constructions develop 
T A B LE 21. All learners' use of the haluta construction at the end of the period of observation

\begin{tabular}{|c|c|c|c|c|c|}
\hline \multirow{2}{*}{$\begin{array}{l}\text { Learner (weeks, } \\
\text { number of } \\
\text { utterances) }\end{array}$} & \multirow{2}{*}{$\begin{array}{l}\text { Number } \\
\text { of forms } \\
\text { of haluta }\end{array}$} & \multirow{2}{*}{$\begin{array}{l}\text { NFC, } \\
\text { number } \\
\text { of verbs }\end{array}$} & \multirow{2}{*}{$\begin{array}{l}\text { Number } \\
\text { of NPs }\end{array}$} & \multicolumn{2}{|c|}{ Degree of productivity } \\
\hline & & & & $\begin{array}{l}\text { Haluta } \\
+\mathrm{NFC}\end{array}$ & $\begin{array}{l}\text { Haluta } \\
+\mathrm{NP}\end{array}$ \\
\hline Lena $(24-36,20)$ & 8 & 13 & 1 & Highly schematic & Highly schematic ${ }^{8}$ \\
\hline Jungo $(26-36,23)$ & 8 & 12 & 1 & Highly schematic & Semi-schematic \\
\hline Alvaro $(19-36,19)$ & 7 & 13 & 2 & Highly schematic & Highly schematic \\
\hline Khadiza $(34-35,23)$ & 3 & 13 & 0 & Highly schematic & Not used \\
\hline
\end{tabular}

${ }^{8}$ Lena's haluta + NP is considered as highly schematic because of code-mixing; see the discussion below

T A B LE 22. All learners' use of the tykätä construction at the end of the period of observation

\begin{tabular}{llllll}
\hline Learner & $\begin{array}{l}\text { Number } \\
\text { of forms } \\
\text { of tykätä }\end{array}$ & $\begin{array}{l}\text { NFC, } \\
\text { number } \\
\text { of verbs }\end{array}$ & $\begin{array}{l}\text { Number } \\
\text { of NPs }\end{array}$ & $\begin{array}{l}\text { Degree of productivity } \\
\begin{array}{l}\text { Tykätä } \\
+ \text { NFC }\end{array}\end{array}$ & $\begin{array}{l}\text { Tykätä } \\
+ \text { NP }\end{array}$ \\
\hline $\begin{array}{l}\text { Lena } \\
(10-34,20)\end{array}$ & 5 & 10 & 8 & Semi-schematic & Highly schematic \\
$\begin{array}{c}\text { Jungo } \\
(10-34,21)\end{array}$ & 5 & 6 & 17 & Semi-schematic & Highly schematic \\
$\begin{array}{c}\text { Alvaro } \\
(14-30,13)\end{array}$ & 4 & 0 & 11 & Not used & Highly schematic \\
$\begin{array}{c}\text { Khadiza } \\
(14-24,20)\end{array}$ & 3 & 4 & 7 & Highly schematic & Highly schematic \\
\hline
\end{tabular}

${ }^{9}$ Alvaro's ends phase does not include as many utterances as the other learners', because in total he uses fewer utterances.

into a semi- or highly productive pattern (see Tables 21 and 22) and there are differences between the learners (see Table 23 for the continuum of abstractness of the constructions). Because free production data were used and the learners produced different numbers of utterances with the haluta and tykätä constructions in different weeks, the length of the end phase is based on the number of utterances with these constructions, not on the points of data collection.

For the haluta construction, the data provide enough evidence that all learners develop a highly schematic [HALUTA + NFC] pattern (see Table 21). However, Khadiza uses fewer forms of haluta than the other learners, and her use of non-finite clauses at datapoint 34 shows that an L2 learner might show very little variation in her constructions even though some degree of schematization has already taken place. Just as for proficient speakers 
TA B LE 23. All learners constructions at the end of the data collection

\begin{tabular}{|c|c|c|c|c|}
\hline & Formulaic & & $\longrightarrow$ & Schematic \\
\hline & $\begin{array}{l}\text { Jungo's haluta }+\mathrm{NP} \\
\text { Lena's and Jungo's tykätä }+ \text { NFC }\end{array}$ & Khadiza's tykätä +NFC & Khadiza's haluta + NFC & Other constructions \\
\hline Patterns used & $\begin{array}{c}{[\text { haluavat }+\mathrm{NP}] \mathrm{J}} \\
{[\text { tykkään }+\mathrm{NFC}] \mathrm{L}, \mathrm{J}}\end{array}$ & [T Y K ̈̈ T $\ddot{A}+\mathrm{NFC}]$ & [HALUTA + NFC] & $\begin{array}{l}\text { [H ALUTA + NFC] L,J,A } \\
\text { [H A LU T A + NP] L,A } \\
{[\text { T Y K ̈̈ T } \ddot{\text { A }}+\mathrm{NP}] \mathrm{L}, \mathrm{J}, \mathrm{A}, \mathrm{K}}\end{array}$ \\
\hline
\end{tabular}


(see Barlow, 2018), prefabricated chunks play an important role in fluent L2 production. Concerning the [HALUTA + NP] pattern, the data are more restricted but there is evidence for semi- or highly schematic patterns. For Lena, the use of a multilingual construction can be seen as evidence for an existing open slot within the construction, as argued in usage-based approaches to bilingual children's code-mixing patterns (Quick, Hartman, Backus, \& Lieven, 2019). Jungo uses one noun phrase within the construction in the last weeks (see Table 21) but he had used another noun phrase earlier. Alvaro uses two different forms of haluta with two different noun phrases in the last weeks, pointing to a schematic pattern.

Regarding the tykätä construction, all learners seem to develop a semi- or highly schematic pattern even though, compared to haluta, fewer different forms are used. This difference does not necessarily tell us something about the difference in productivity between different constructions, but rather about the differences in their use: haluta is a more versatile construction in terms of use, and is simply more frequent overall. The [т к ӥ тё + NP] pattern seems to become highly abstract for all four learners. Although Lena and Khadiza use fewer different NPs than initially, these NPs are combined more variably with different forms of tykätä. In contrast, with [T Y K ̈̈ T $\ddot{A}+$ NFC], individual differences are more visible. Both Lena and Jungo use variable non-finite clauses only with the first person singular form. Therefore, their data do not support the idea of a fully abstract [T Y К ̈̈ T $\ddot{A}+$ NFC] pattern. This finding is consistent with Eskildsen (2008), who showed that an L2 English learner's can construction did not develop into a fully abstract construction, but that the learner's linguistic inventory consisted of interconnected utterance schemas.

As described, the four learners differ to some extent in both the initial and the later use of the haluta and tykätä constructions. Reasons for the differences in learning trajectories can be speculated upon. One individual difference is the time of residence before the study. Lena and Alvaro arrived in Finland just before the study, but Jungo and Khadiza had already been in Finland for some time. The time of residence before the study presumably influences the amount of exposure before the data collection, which in turn might affect the learning trajectories. If we assume that the earlier exposure to (and presumably use of) the language plays a role, we would expect, based on the usage-based approaches, that Alvaro and Lena are more formulaic with their constructions initially than Jungo and Khadiza. However, our results show a more mixed picture. Even though Lena is formulaic with the haluta construction, she is productive with tykätä, and Alvaro is productive with both. Jungo's haluta construction, in turn, is more formulaic than Alvaro's haluta construction initially. In other words, it seems that the longer time of residence before the 
study and therefore the supposed greater amount of exposure does not explain the differences between the learners.

Another difference is the L1 of the learners, which might have enabled positive (or negative) transfer. It could be assumed that, if there is a similar construction in the L1, positive transfer may happen, and the learner may develop a productive construction relatively quickly. Our data do not support this hypothesis, however. Lena and Alvaro, who both have the want $+\mathrm{NFC}$ structure in their L1 (German and Spanish), develop the corresponding Finnish construction in a different way: Lena starts off with a chunk, and Alvaro with a productive pattern. In sum, however, the data are too restricted to allow any firm conclusions in this respect.

\section{Conclusion}

The aim of this study was to investigate whether two verbal constructions of four beginner learners of L2 Finnish develop from lexically specific to more productive constructions over time. The findings of this study demonstrate that some learners start with lexically specific, formulaic expressions rooted in a specific communicative function, while the constructions used by other learners exhibit a greater number of variable instantiations initially and are therefore more productive. On the one hand, these results support the view of L2 learning as item-based (see, e.g., Eskildsen, 2008); on the other hand, they show that L2 learners may start off with a more productive and abstract pattern, as shown earlier by Roehr-Brackin (2014). The use of these more abstract patterns might be explained by the influence of already established language systems, especially the L1, and the L2 instruction. Despite these individual differences in learning trajectories, over time all learners in our study moved towards more abstract schemas, confirming the assumed usagebased learning path from more specific to more schematic patterns. We also show that, for some learners, chunk-like expressions not only characterize the early stages of L2 development but are also used later on. This study has also shown that, even in the early stages, L2 learners may use both bottom-up and top-down processes. This can be seen especially in the non-target-like forms used by learners, as they have not been picked up from exposure as chunks but formed by applying a pattern.

Of course, this study has its limitations. When using free production data, which allowed us to investigate more or less spontaneous L2 production, a possible task effect cannot be ruled out completely: the task might have guided the learners to use some forms more frequently than others. Moreover, even though the length of residence prior to the start of the data collection did not 
seem to lead to principled differences in the development of our learners, a denser data collection period, especially in the beginning phases of L2 development, would have given us a more precise picture of the (possible) use of formulaic expressions. Finally, our sample size was small, which makes it difficult to draw broader conclusions. But our findings suggest something general about L2 learning mechanisms: we have shown that starting with fixed patterns might be less of a default in L2 learning that assumed from a traditional cognitive linguistic point of view.

In a further study, it would be fruitful to investigate L2 learners' construction development in more natural communication situations in different contexts. In order to investigate whether L2 learners develop abstract constructions even if "no specific lexical sequence is repeated" (Langacker, 2009, p. 633), we need more and denser data.

\section{REFERENCES}

Arndt-Lappe, S. \& Baldus, L. (2018). How do frequency, granularity, and proficiency interact in the L2 acquisition of alternations? Evidence from German-English syntax and morphophonology. Paper presented at EuroSLA28.

Barlow, M. (2018). Entrenchment in production and comprehension systems. Paper presented at DGKL8.

Common European Framework for Languages: Learning, teaching, assessment. (2006). Cambridge: Cambridge University Press.

Dąbrowska, E. \& Lieven, E. (2005). Towards a lexically specific grammar of children's question constructions. Cognitive Linguistics 16(3), 437-474.

Ellis, N. (2002). Frequency effects in language processing. Studies in Second Language Acquisition 24(2), 143-188.

Ellis, N. \& Cadierno, T. (2009). Constructing a second language: introduction to the special section. Annual Review of Cognitive Linguistics 7(1), 111-139.

Eskildsen, S. \& Cadierno, T. (2007). Are recurring multi-word expressions really syntactic freezes? Second language acquisition from the perspective of usage-based linguistics. In M. Nenonen \& S. Niemi (eds), Collocations and idioms 1: Papers from the first Nordic conference on syntactic freezes. (pp. 86-99). Joensuu: Joensuu University Press.

Eskildsen, S. (2008). Constructing another language: usage-based linguistics in second language acquisition. Applied Linguistics 30(3), 335-357.

Eskildsen, S. (2012). L2 Negation constructions at work. Language Learning 62(2), 335-372.

Eskildsen, S. (2015). What counts as a developmental sequence? Exemplar-based L2 learning of English questions. Language Learning 65(1), 33-62.

Eskildsen, S. (2018). L2 constructions and interactional competence: subordination and coordination in English L2 learning. In A. Tyler, L. Huang \& H. Jan (eds), What is applied cognitive linguistics? (pp. 63-98). Berlin, Boston: De Gruyter.

Goldberg, A. (1995). A construction grammar approach to argument structure. Chicago, IL: University of Chicago Press.

Goldberg, A. (2006). Constructions at work: the nature of generalization in language. Oxford: Oxford University Press.

Gustafsson, H. (2019). Making do: constructing L2 phraseological chunks as complex formmeaning mappings. Review of Cognitive Linguistics 17(2), 382-410. 


\section{LESONEN ET AL.}

Hopper, P. (1998). Emergent grammar. In M. Tomasello (ed.), The new psychology of language: cognitive and functional approaches to language structure (pp. 155-175). Mahwah, NJ: Lawrence Erlbaum Associates.

Langacker, R. (1987). Foundations of cognitive grammar: theoretical prerequisites. Stanford, CA: Stanford University Press.

Langacker, R. (2009). A dynamic view of usage and language acquisition. Cognitive Linguistics 20(3), 627-640.

Langacker, R. (2013). Essentials of cognitive grammar. Oxford: Oxford University Press.

Lesonen, S., Suni, M., Steinkrauss, R. \& Verspoor, M. (2017). From conceptualization to constructions in Finnish as an L2: a case study. Pragmatics $\Xi^{\circ}$ Cognition 24(2), 212-262.

Mellow, J. (2006). The emergence of second language syntax: a case study of the acquisition of relative clauses. Applied Linguistics 27(4), 645-670.

Peters, A. (1983). The units of language acquisition. Cambridge: Cambridge University Press.

Quick, A., Hartman, S., Backus, A. \& Lieven, E. (2019). Entrenchment and productivity: the role of input in the code-mixing of a German-English bilingual child. Applied Linguistics Review. https://doi.org/10.1515/applirev-2019-0027

Roehr-Brackin, K. (2014). Explicit knowledge and processes from a usage-based perspective: the developmental trajectory of an instructed L2 learner. Language Learning 64(4), 771-808.

Roos, J. \& Lenzing, A. (2018). Towards independent language use: the role of formulaic sequences in the developing L2 system. Paper presented at the 28TH Conference of the European Second Language Association, Münster, Germany, 5-8 September.

Sag, I. (2012). Sign-based construction grammar: an informal synopsis. In H. Boas \& I. Sag (eds), Sign-Based Construction Grammar (pp. 69-202). Stanford, CA: CSLI Publications.

Tomasello, M. (2003). Constructing a language. a usage-based theory of language acquisition. Cambridge, MA: Harvard University Press.

VISK = A. Hakulinen, M. Vilkuna, R. Korhonen, V. Koivisto, T. R. Heinonen \& I. Alho (2004). Iso suomen kielioppi [Comprehensive Finnish Grammar Online]. Helsinki: Suomalaisen Kirjallisuuden Seura. Electronic Database [29.12.2017]. Retrieved from <http://scripta.kotus.fi/visk>.

\section{Appendix}

\section{Glossing}

$\begin{array}{ll}\text { A DE } & \text { adessive ('at, on') } \\ \text { A L L } & \text { allative ('to') } \\ \text { C O D } & \text { conditional } \\ \text { E L A T } & \text { elative ('out of') } \\ \text { GEN } & \text { genitive (possession) } \\ \text { I L L } & \text { illative ('into') } \\ \text { INE } & \text { inessive ('in') } \\ \text { IN F } & \text { infinitive } \\ \text { NEG } & \text { negation (an auxiliary verb in Finnish) } \\ \text { P AR } & \text { partitive (partitiveness) } \\ \text { P L } & \text { plural } \\ \text { POSS } & \text { possessive } \\ \text { P PC } & \text { past participle }\end{array}$


PRODUCTIVENESS OF L 2 CONSTRUCTIONS

$\begin{array}{ll}\text { PST } & \text { past tense } \\ \mathrm{Q} & \text { interrogative } \\ \mathrm{SG} & \text { singular } \\ 1 & \text { first person ending } \\ 2 & \text { second person ending } \\ 3 & \text { third person ending } \\ 3 . \mathrm{INF} & \text { third infinitive (ma infinitive) }\end{array}$

